\title{
Wolf-Parkinson-White syndrome in young men presenting with palpitation: the pattern of delta waves in predicting location of accessory pathway
}

\author{
Miryanti Cahyaningtias, ${ }^{1}$ Mohammad S. Rohman, ${ }^{2}$ Dicky A. Hanafy ${ }^{2}$ \\ ${ }^{1}$ Department of Cardiology and Vascular Medicine, Medical Faculty of Brawijaya University /Dr. Saiful Anwar Hospital, \\ Malang, Indonesia \\ ${ }^{2}$ Department of Cardiology and Vascular Medicine, Medical Faculty of Universitas of Indonesia/Harapan Kita Cardiovascular \\ Centre Jakarta, Indonesia
}

\begin{abstract}
Abstrak
Palpitasi merupakan keluhan yang paling sering membuat seorang penderita datang ke unit gawat darurat. WolfParkinson White (WPW) syndrome merupakan gangguan konduksi pada jantung dengan gejala palpitasi yang dapat menyebabkan kematian mendadak. WPW dapat dideteksi dengan pemeriksaan electrocardiogram (EKG). Dalam tulisan ini dilaporkan dua kasus WPW yang terjadi pada usia muda dengan riwayat keluhan palpitasi yang berulang dan progresif. EKG pasien pertama menunjukkan takikardi supraventrikel yang berubah menjadi irama sinus setelah pemberian propanolol. Pada EKG dengan irama sinus ditemukan gelombang delta pada sandapan II,III, aVF, V1 yang biasanya disebabkan oleh accessory pathway (AP) pada dinding left lateral. Studi elektrofisiologi mengkonfirmasi adanya AP dan radio frequency catheter ablation berhasil dilakukan, Gelombang delta tidak terdeteksi pada saat pasien kontrol ke poliklinik. Pasien tidak ada keluhan dan tidak harus minum obat lagi. EKG pasien kedua menunjukkan takikardi supraventrikel dengan aberansi. Setelah pemberian amiodarone terekam irama sinus dengan gelombang delta pada sandapan I,II, aVL, kemungkinan accessory pathway pada dinding anteroseptal. Pasien kedua tidak dilakukan studi elektrofisiologi dan ablasi karena masalah biaya, namun amiodarone perlu diminum untuk mencegah takikardi supraventrikel berulang. (Med J Indones 2011; 20:298-301)
\end{abstract}

\begin{abstract}
Palpitation is a common presenting symptom in the emergency department. Wolf-Parkinson White (WPW) syndrome is a cardiac conduction disorder that may present with palpitation and lead to sudden cardiac death. WPW could be detected by electrocardiogram (ECG). In this case report, we present two young male patients with WPW syndrome admitted to our hospital with history of repeated and progressive palpitation. ECG of the first patient revealed supraventricular tachycardia which converted to sinus rhythm after propanolol treatment. ECG showed sinus rhythm with delta wave in lead II,III,aVF, V1 suggesting the presence of accessory pathway (AP) in left lateral wall. Electrophysiology study confirmed the presence of AP and radio frequency catheter ablation was successfully done resulted in disappearance of delta on outpatient clinic ECG. Patient has no symptom and he do not have to take medication. ECG of the second patient revealed supraventricular tachycardia with abberancy. After amiodarone infusion, ECG showed sinus rhythm with delta wave in lead I,II,aVL suggesting the presence of accessory pathway in anteroseptal wall. Electrophysiology study and catheter ablation did not perform for this patient because of financial problem, however amidarone has to be taken regularly to prevent the recurrence of supraventricular tachycardia. (Med J Indones 2011; 20:298-301)
\end{abstract}

Keywords: ECG, palpitation, supraventricular tachycardia, Wolf-Parkinson White syndrome

Palpitation is a common presenting symptom in the emergency department. ${ }^{1}$ Palpitation may occur due to various causes ranging from a mild problem to a lifethreatening disease. Wolf-Parkinson White (WPW) syndrome due to its abnormal electrical conductivity of the heart that can result in sudden death, has to be considered in patients who come with palpitation. ${ }^{2-4}$ WPW syndrome, which is classified among the paroxysmal supraventricular tachycardias (PSVTs), ${ }^{4,5}$ is a relatively uncommon cardiac conduction disorder that occasionally may cause early excitation (preexcitation) of the ventricles due to antegrade ventricular (AV) conduction through an accessory pathway. Accessory pathways are anomalous, typically extranodal connections that connect the epicardial surfaces of the atrium and ventricle along the AV groove and detectable on ECG. Accessory pathway is reportly present in 0,15 to 0,25 percent of the general population. ${ }^{1,4}$ Early detection of symptomatic
WPW syndrome can give appropiate treatment and save patient's life from suddent cardiac death. ${ }^{3,4,6-10}$

\section{CASE REPORT}

A 19 year-old man, came with chief complain of palpitation while watching television 1 day prior to admission, his palpitation was not relieved by rest. The history of recurrent palpitations induced by exercise occurred since he was 17 years old, usually relieved by rest. No history of syncope was reported. On physical examination, blood pressure was $95 / 66 \mathrm{mmHg}$ with pulse rate of 254 beat per minute (bpm). No other abnormalities were observed in his physical examination. ECG recording revealed narrow complex tachycardia with rate of $250 \mathrm{bpm}$, no $\mathrm{P}$ waves visible, normal axis, normal QRS complexes, so the conclusion was supraventricular tachycardia (figure 1a). Laboratory examination did not reveal serum electrolyte abnormality. 
After $40 \mathrm{mg}$ propanolol treatment, the ECG showed sinus rhythm with QRS rate of $88 \mathrm{bpm}$. PR interval $(0,10$ ") shortening, slurred QRS complex (delta wave) and widened QRS complex was observed (figure 1b)

Positive delta in lead II,III, aVF and V1 suggesting the presence of accessory pathway in left lateral wall which was confirmed by electrophysiology study performed in Harapan Kita National Cardiovascular Center, Jakarta, Indonesia. Radio frequency catheter ablation was successfully done resulted in disappearance of delta wave and normal PR interval and QRS duration (figure 2). The patient visited our outpatient clinic without anti arrhythmic medication and symptom-free 1 month after ablation.

Second patient, a 18 year-old man, came with chief complain of chest pain when he turned on his motorcycle 3 days before admission, it was not relieved by rest. The pain did not radiate to the left arm, back nor left lower jaw. His chest pain was accompanied with palpitation. His palpitation was also not relieved by rest. In the history, palpitation has appeared since he was 17 years old triggered by emotional stress. He is an active smoker and consumes alcohol.No history of syncope was reported. On physical examination, blood pressure was $117 / 73 \mathrm{mmHg}$ with regular pulse rate of $208 \mathrm{bpm}$. No other abnormalities were observed in his physical examination. ECG recording revealed wide complex tachycardia with rate of $214 \mathrm{bpm}$ with normal axis, there was no $\mathrm{AV}$ dissociation nor $\mathrm{AV}$ concordance, so the conclusion was SVT with abberancy (figure 3). No abnormality in serum electrolytes was observed.

Sinus rhythm was restored by intravenous $150 \mathrm{mg}$ amiodarone infusion. ECG analysis showed sinus rhythm with rate of $88 \mathrm{bpm}$, normal axis, shortened PR interval $(0,10$ "), slurred and widened QRS complex (delta wave) and inverted $\mathrm{T}$ in inferior leads. Positive delta wave were noticed in lead I, II and aVL, whereas negative delta wave was observed in V1. The pattern of delta wave observed suggesting an anteroseptal accessory pathway (figure $3 b$ ).

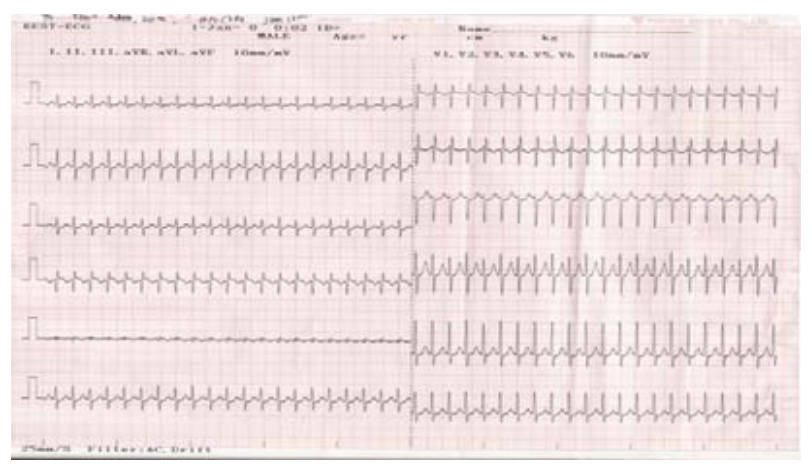

Figure 1a. Supra ventricular tachycardia of a 19 year-old man, came with chief complain of palpitation. ECG recording revealed narrow complex tachycardia at $250 \mathrm{bpm}$, no $P$ waves visible, normal axis with normal QRS complexes
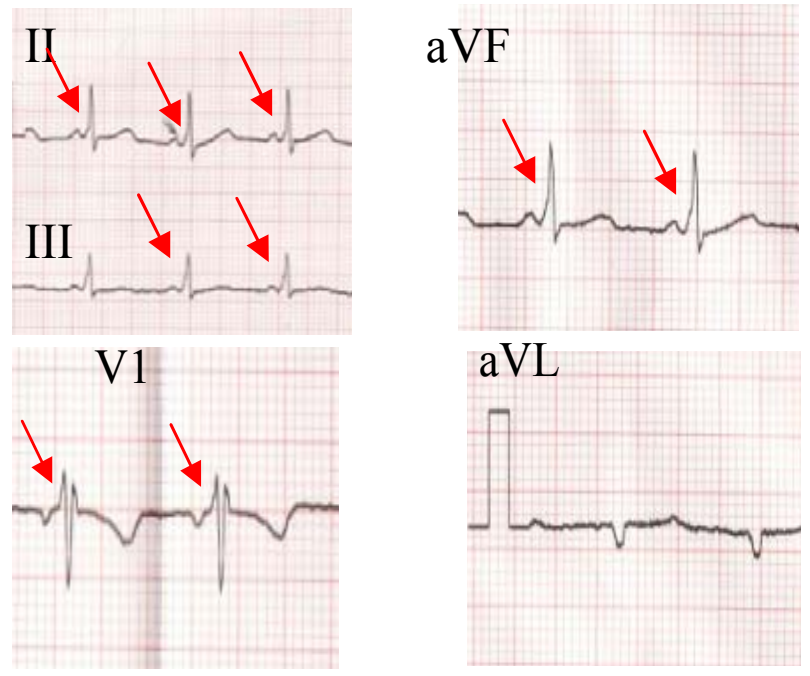

Figure 1b. ECG of 19 year-old man, came with SVT after propanolol treatment and converted to sinus rhythm. Positive delta wave was observed in lead II,III, aVF and VI, negatif in aVL suggesting that bypass tract may exist at left free wall
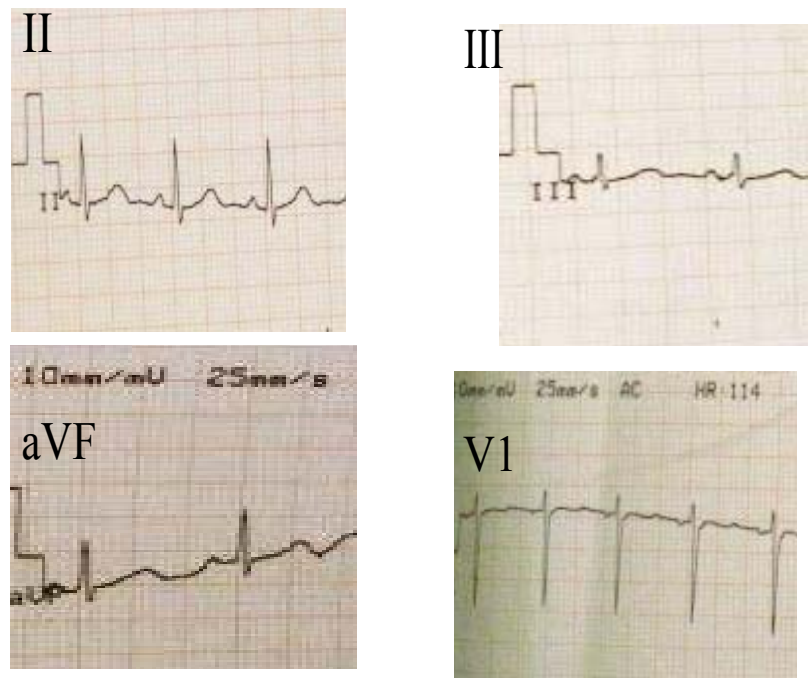

Figure 2. ECG after catheter ablation. Representative of ECG lead revealed no delta wave in lead II,III, aVF and VI

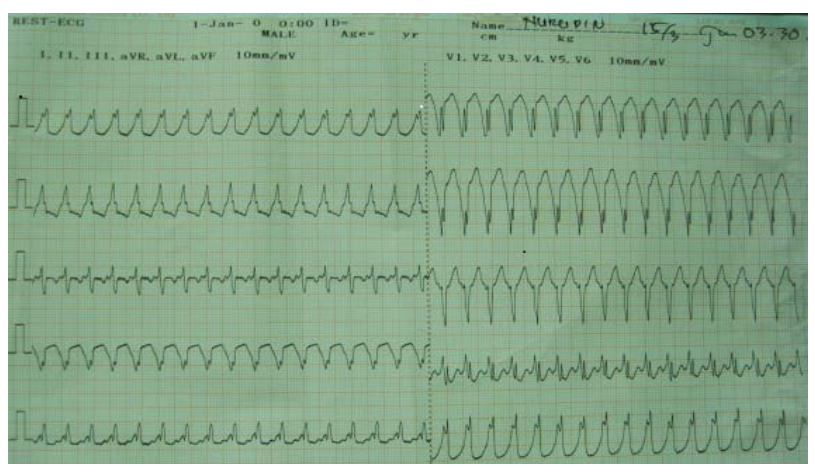

Figure 3a. Supra ventricular tachycardia with abberancy in a 18 year-old man, came with chief complaint of palpitation. ECG recording revealed wide complex tachycardia with rate of $214 \mathrm{bpm}$, normal axis, clockwise rotation, there was no AV dissociation nor AV concordance 

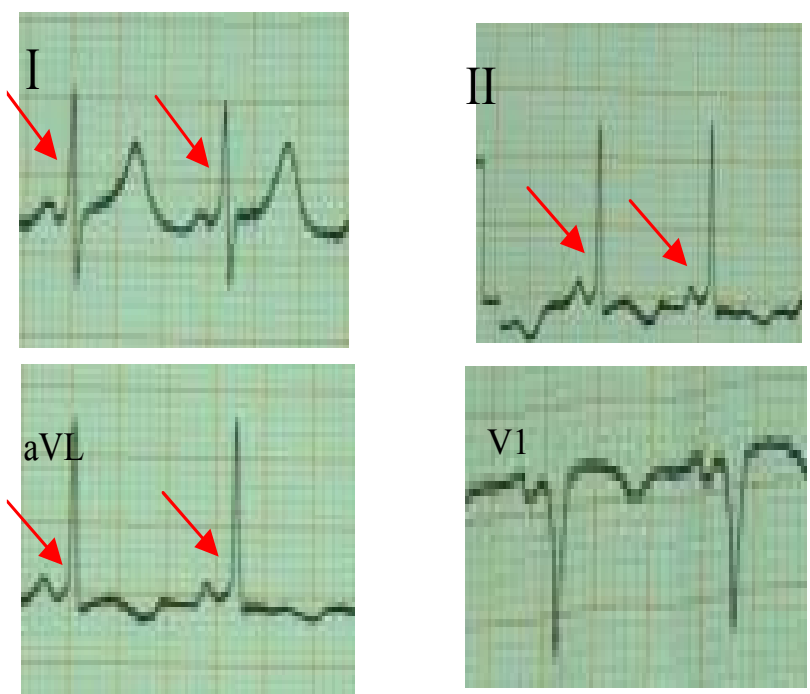

Figure 3b. ECG of aberrant SVT after amiodarone infusion. ECG analysis showed sinus rhythm with rate of $88 \mathrm{bpm}$, normal axis, shortened PR interval (0,10"), slurred and widened ORS complex (delta wave) and inverted $T$ in inferior lead. Positive delta wave was observed in lead I,II and aVL and negative delta wave in V1 suggesting the presence of bypass tract at anteroseptal wall.

\section{DISCUSSION}

We have reported two young men presenting with palpitation. Their ECG showed slightly different features. ECG of the first patient revealed supraventricular tachycardia with narrow QRS complex, while ECG of second one revealed supraventricular tachycardia with abberancy. SVT with abberancy is different from VT because it has wide QRS complex without AV disssociation and without AV concordance.

After conversion to sinus rhythm, there were apparent delta waves observed in ECG recording, suggesting the presence of accessory pathways of WPW. The diagnosis criteria of WPW consist of short PR interval $(<0,12$ "), slurred QRS complex (delta wave) and widened QRS complex. . $^{611-13,16}$

ECG delta wave pattern in WPW can guide us to predict the location of the bypass tract or accessory pathway (AP) based on different pattern of delta wave in lead I, aVL, II, III, aVF, V1. Numerous algorithms have been described to localize the site of the AP using the axis of the delta wave and QRS morphology. ${ }^{6,11,14-16}$

46 to 60 percent of the pathways are found on the left free wall space. Nearly 25 percent are within the posteroseptal and midseptal spaces, 15 to 20 percent in the right free wall space, and 2 percent in the anteroseptal space. ${ }^{6,11,12,14-16}$ Of all pathways described in reports of symptomatic patients, $2 \%$ to $3 \%$ conduct in an anterograde direction only, whereas $20 \%$ to $31 \%$ conduct in the retrograde/ventricular-to-atrial direction only. ${ }^{6}$
Population-based studies have suggested that $50 \%$ to $60 \%$ of patients with WPW pattern show symptoms ranging from palpitations to syncope. Other symptoms may include dyspnea, decreased exercise tolerance, chest discomfort or tightness, anxiety, dizziness, presyncope, or syncope., ${ }^{4,6,11}$

A concern for patients with ventricular preexcitation or WPW pattern is the potential for an increased risk of sudden cardiac death (SCD), ${ }^{3,4,7-11}$ because patients with WPW are likely to have reccurent tachycardia. ${ }^{6}$ The degree of risk for SCD is related, in part, to the symptom status of the patient at the time of initial evaluation. In symptomatic patients evaluated at tertiary referral centers, the prevalence of patients with a history of aborted SCD is $2 \%$ to $11 \%$. In one study this was found to be 0.0015 events per patient-year, or approximately $0.15 \%$ per year, occurring exclusively in previously symptomatic individuals. ${ }^{11}$

Electrophysiology (EP) study in patients with AVRT is done to not only confirm the presence of an AP and differentiate this condition from other forms of SVT but also to find the pathway participating in the tachycardia and aid in ablative therapy. ${ }^{11}$ Catheter ablation is considered first-line therapy (class 1) and the treatment of choice for patients with WPW syndrome i.e., patients with manifest preexcitation along with symptoms. ${ }^{6,7,13}$ It is curative in more than 95 percent of patients and has a low complication rate. ${ }^{17}$ It also obviates the unwanted side effects of antiarrhythmic agents. 6 Radio frequency catheter ablation of SVT has been shown to be cost-effective and improve quality of life for patients with WPW who survive cardiac arrest or who experience SVT or AF and for highly symptomatic patients with SVT. ${ }^{11,18}$

In these presented cases, catheter ablation was the treatment of choice for the first patient. Previous study revealed that the success rate for catheter ablation of left free-wall APs is slightly higher than for catheter ablation of right-sided APs (95 vs. 90 percent, $p=0.03$ ). Following an initially successful procedure, recurrence of AP conduction is found in approximately 5 percent of patients. ${ }^{6}$ The second patient didn't perform catheter ablation because of financial problem. The anteroseptal pathway is located in close contiguity to the normal AV conduction system so radiofrequency catheter ablation in this region may be asscociated with slightly increased risk of iatrogenic complete heart block. ${ }^{11}$

In conclusion, Two cases have been presented with different types of SVT morphology of ECG on admission. After converting to sinus rhythm the pattern of delta wave can predict the accessory pathway site. Electrophysiologic study with radiofrequency catheter ablation confirms the accessory pathway in the first patient 
and prevents recurrence of symptoms without the need for anti arrhythmic drugs.

\section{REFERENCES}

1. Begleiter DE, Gernsheimer J, Waseem M.Wolff-ParkinsonWhite syndrome: An uncommon causes of palpitations. Hosp Physician. 2007;43:49-54.

2. Yalamanchili M, Khurana A, Smaha L. Evaluation of palpitations: etiology and diagnostic methods. Hosp Physician. 2003;39:53-8.

3. Kulig J, Koplan BA. Wolff-Parkinson-White syndrome and accessory pathways. Circulation. 2010; 122:e480-3.

4. Sidhu J, Roberts R. Genetic basis and pathogenesis of familial WPW syndrome. Indian Pacing Electrophysiol J. 2003;3:197-201.

5. Tu CM, Chu KM, Cheng CC, Cheng SM, Lin WS. Reversion of left ventricular systolic dysfunction and abnormal stress test by catheter ablation, in a patient with WolffParkinson- White syndrome from Para-Hisian Kent bundle. Tex Heart Inst J. 2010;37:483-5.

6. Calkins H. Supraventricular tachycardia: AV nodal reentry and Wolff-Parkinson-White syndrome. In: O'Rourke RA, Walsh RA, Fuster V. Editors. Hurst's the Heart. 12th ed. Singapore: McGraw Hill;2009.p 983-1002.

7. ACC/AHA/ESC guidelines for the management of patients with supraventricular arrhythmias: executive summary: a report of the American College of Cardiology/American Heart Association Task Force on Practice Guidelines and the European Society of Cardiology Committee for Practice Guidelines. J Am Coll Cardiol. 2003;42:1493-531.

8. Erdem A, Madak N, Yilmaz A, Yontar OC, Yucel H, Gul I, et al. Development of malignant ventricular arrhythmias in a young male with WPW Pattern. Indian Pacing Electrophysiol J. 2010;10:195-200.

9. Wellens HJ. When to perform catheter ablation in asymptomatic patients with a Wolff-Parkinson-White electrocardiogram. Circulation. 2005; 112:2201-16.

10. Pappone C, Radinovic A, Santinelli V. Sudden death and ventricular preexcitation: is it necessary to treat the asymptomatic patients?. Curr Pharm Des. 2008;14:762-5.

11. Schweikert RA, Packer DL. Atrioventricular nodal dependent tacycardias and preexcitation. In: Topol EJ, editor. Textbook cardiovascular medicine. 3rd ed. Philadelphia: Lippincott Williams and Wilkins; 2007. p 1077-92.

12. Fogoros RN. The electrophysiology study in the evaluation of supraventricular arrhythmia. In: ElectrophysiologicTesting. 4th ed. Australia: Blackwell Publishing; 2006. p 131-42.

13. Rolls HK, Stevenson WG, Strichartz GR, Lilly LS. Mechanisms of cardiac arrhythmias. In: Lily LS, Editor. Pathophysiology of heart disease. 4th ed. USA: Lippincott Wiliams \& Wilkins; 2007. p 280-302.

14. Soo WM, Chong E, Teo SG, Poh KK. ECG delta waves in patients with palpitation. Singapore Med J. 2011;52:68.

15. Gautam MP, Thapa L, Gautam S. Wolff - Parkinson-White syndrome presenting as atrial fibrillation with broad-QRS complexes. JCMS-Nepal. 2010;6:52-7.

16. Kaushik ML, Sharma M, Ganju N. Wolff - Parkinson White syndrome presenting as atrial fibrillation with wideQRS complexes. J Indian Acad Clin Med. 2003; 4:152-55.

17. Adao L, Araujo C, Sa AP, Silva P, Oliveira M, Goncalves $\mathrm{H}$ et al. Importancia da posicao anatomica da via acessoria na eficacia e na seguranca da ablacao por radiofrequencia . Rev Port Cardiol. 2011;30:35-46.2010-AO-

18. Olgin JE, Zipes DP. Specific arrhythmia: Diagnosis and treatment. In: Libby P, Bonnow RO, Mann DL, Zipes DP, editors. Braunwald's Heart Disease: A textbook of cardiovascular medicine. 8th ed. Philadelphia:Sauders Elsevier; 2008.p 882-93. 